\title{
IDENTIFICATION OF THE HERBAL DRUG PRUNELLAE SPICA BASED ON MACROSCOPIC AND MICROSCOPIC CHARACTERISTICS
}

\author{
Alexandra GROȘAN ${ }^{1}$, Ruxandra ȘTEFĂNESCU ${ }^{2 *}$, Eszter LACZKÓ-ZÖLD ${ }^{2}$, Sigrid EŞIANU ${ }^{2}$, \\ Daniela Lucia MUNTEAN ${ }^{3}$
}

\begin{abstract}
${ }^{1}$ Department of Pharmacology and Clinical Pharmacy, Faculty of Pharmacy, University of Medicine, Pharmacy, Science and Technology of Târgu Mureș, Romania

${ }^{2}$ Discipline of Pharmacognosy and Phytotherapy, Faculty of Pharmacy, University of Medicine, Pharmacy, Science and Technology of Târgu Mureș, Romania

${ }^{3}$ Department of Analytical Chemistry and Drug Analysis, Faculty of Pharmacy, University of Medicine, Pharmacy, Science and Technology of Târgu Mureș, Romania
\end{abstract}

\author{
*Correspondence: \\ Ruxandra ȘTEFĂNESCU \\ ruxandra.braic@yahoo.com, ruxandra.stefanescu@umfst.ro
}

Received: 3 June 2019; Accepted: 17 June 2019; Published: 30 June 2019

\begin{abstract}
Prunella vulgaris L. belongs to the genus Prunella, Lamiaceae family, Nepetoideae subfamily. In Romania, the genus Prunella includes Prunella vulgaris L., Prunella grandiflora (L.) Jacq and Prunella laciniata L.. Amongst these, Prunella vulgaris is of particular importance, having numerous pharmacological actions. The purpose of this study is to analyze macroscopically and microscopically the main characters by which Prunellae spica can be identified and distinguished from other fruit-spikes from species of the Lamiaceae family.
\end{abstract}

Keywords: Prunellae spica, nutlets, histo-anatomical characteristics.

\section{Introduction}

Most species of the Lamiaceae family are aromatic plants that grow in many regions of the world. They are an essential source of phytochemical compounds that have beneficial effects in relieving certain conditions (Kozlowska et al., 2015). According to the new classification, the Lamiaceae family comprises seven subfamilies, about 230 genera and over 7.000 species with international distribution, but are rare or absent from highaltitudes and cold regions. Many species of this family are economically important due to the production of volatile oil (Tamaş, 1999; Dinç et al., 2009; Dinç and Dogu, 2012). The Prunella genus is a member of the Lamiaceae family, Nepetoideae subfamily. Among the species of this genus, Prunella vulgaris L., Prunella grandiflora (L.) Jacq and Prunella laciniata L. grow in the wild flora of Romania. Prunella vulgaris L., the species under study, grows in wetlands, plains, meadows, pastures, unpopulated areas, uninhabited lawns, both in the sun and the shade (Hodișan and Pop, 1976; Duke, 2001; Sârbu et al., 2013). According to the European Pharmacopoeia, 8th edition, the vegetable drug Prunellae spica represents the 
fruit-spike of Prunella vulgaris L.. Phytochemical studies conducted so far on Prunella vulgaris L. have revealed the presence of triterpenoid, phenol carboxylic acids, flavonoids, triterpenoid saponins, and vitamins (Gu et al., 2007; Khare, 2007; Hon-Yeung and Qing-Feng, 2008).

The species Prunella vulgaris L. (selfheal) is widely used in traditional medicine in Asian countries, especially in China. In Romania, although is commonly spread in the wild flora, selfheal is rarely used in folk medicine.

The beneficial effects of Prunella vulgaris L. have been proven by pharmacological and/or clinical research, especially by Chinese researchers. Antiviral, antibacterial, antiinflammatory, antioxidant, antihyperglycemic, hypolipidemic, antitumoral, hypotensive, sedative actions have been highlighted. The decoction of Prunella vulgaris L. has a broad antibacterial spectrum. In vitro experiments have shown that it has a moderate inhibitory activity on gram-positive bacteria (Psotova et al. 2003). The alcoholic extract of Prunella vulgaris $\mathrm{L}$. reduces serum urea, creatinine and proteinuria in diabetic rats (Feng, 2000). In one study it was demonstrated that certain fractions of the ethanolic extract significantly reduced the cytotoxic effects of various cancer cell lines (Hwang, 2013).

The aerial part of Prunella vulgaris contains a high percentage of triterpenoids, the most important being the oleanolic acid and ursolic acid. Besides these compounds, important phenolic acids have also been identified in this herbal drug: rosmarinic acid, $p$-coumaric acid, caffeic acid, etc. A part of these compounds have antitumor activity, acting through several mechanisms (Huynh and Teel, 1999; Trochon et al., 2000; Raafat, 2016; Wang et al, 2019)

Studies on the action of aqueous and alcoholic extracts have highlighted the hypotensive effect on experimental animals.
Studies on antihypertensive action are controversial. The compounds considered to be responsible for the antihypertensive activity are ursolic acid and oleanolic acid isolated from the methanolic extract (Mohsen and Ammar, 2009; Gu et al., 2013).

This study aimed to describe the macroscopic and microscopic characters by which Prunellae spica can be authenticated, considering the morphological resemblances with other species from Lamiaceae familly like Ajuga decumbens and Ajuga ciliata.

\section{Materials and Methods}

Prunella vulgaris L. was harvested from Mureș County, Romania, in dry weather during flowering and at the end of the flowering period when the fruit develops (Fig. 1A).

The dried herbal drug (the fruit-spike) was soaked in water to achieve the desired consistency. The nutlets were softened in hydroalcoholic solution (ethanol/water in a 1:2 ratio).

For the macroscopic analysis of the nutlets, a Jena-Zeiss stereomicroscope and the Nikon d7100 camera, $60 \mathrm{~mm}$ lens, f22, shutter speed 350 iso 200 were used.

The microscopic analysis was performed with the MICROS-Austria microscope with a video camera.

Transverse sections of the softened samples were done with a single-edged razor blade. The sections and powder fragments have been cleared by boiling in $80 \%$ chloral hydrate solution for 5 minutes, followed by rinsing with water. Preparations were mounted with glycerin-gelatin ( $8 \%$ gelatin).

\section{Results}

The fruit-spike Prunellae spica (Fig. 1B) has a slightly flattened cylindrical shape, is 1.5$8 \mathrm{~cm}$ long and $0.8-1.5 \mathrm{~cm}$ wide, and has a light brown or reddish-brown color. It consists of 10 or more persistent whorls, each whorl being 
delimited by two opposite, fan-shaped bracteoles, with acuminated tip, with reticulate venation, the outer surface being covered with numerous, conspicuous covering trichomes. Each bracteole is grown together at the base with three flowers made up of a persistent biconvex calyx, a corolla that usually lacks and four brown nutlets, small and obovate, with a white, sharp protuberance at the hilum. At the fruiting stage, the calyx is closed. The powdered herbal drug is reddish-brown or brown.

\subsection{Macroscopic analysis of the nutlets}

The The nutlets are obovate, about 1-1.5 mm long, brown, smooth, glossy (Fig. 2). They are characterized by particular surface ornamentation: from the apical rounded region, three lighter colored stripes run down to the pyramidal abscission scar (Fig. 3A, B, C, D), delineating a dorsal convex side and two ventral, slightly flattened sides. After soaking in water, the nutlets produce mucilage (phenomenon called myxocarpy) and show a transparent, dense, layer of mucilage (Fig. 4).
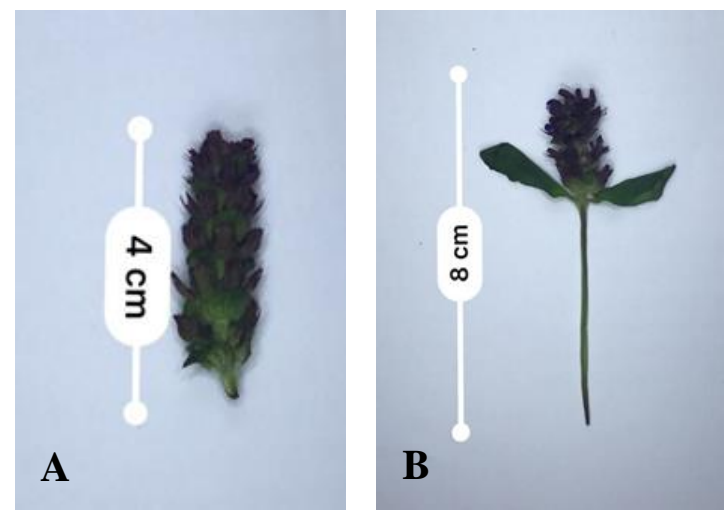

Fig. 1. Prunellae spica (A); Prunella vulgaris L. (B) (Photos: Alexandra Groșan)
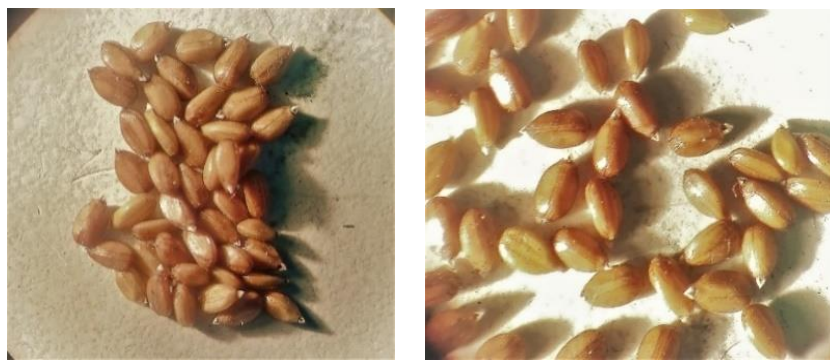

Fig. 2. Nutlets viewed at the stereomicroscope (25x) (Photos: Alexandra Groșan)
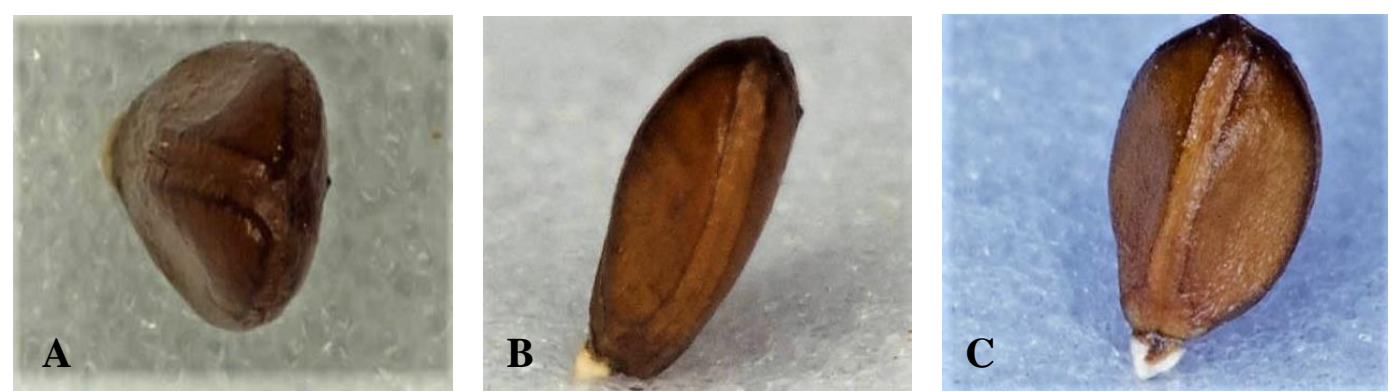

Fig. 3. Nutlets photographed with a Nikon camera (f22, iso $600,60 \mathrm{~mm}$ macro objective, flash):

A. Three stripes form an Y-shaped mark in the apical region; B.-C. Nutlets in side view - stripe running down from the apix to the pyramidal abscission scar covered with white tissue

(Photos: Alexandra Groșan) 


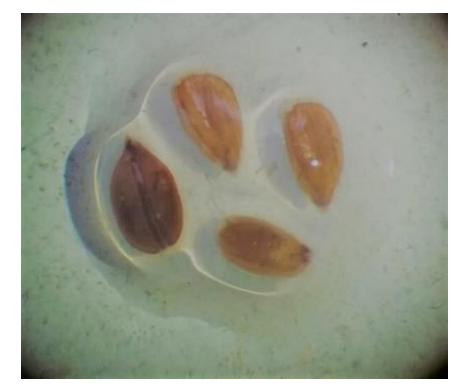

Fig. 4. Nutlets viewed at the stereomicroscope, covered with a transparent, firm layer of mucilage (f22, iso 600, $60 \mathrm{~mm}$ macro objective, flash) (Photo: Alexandra Groșan)

\subsection{Microscopic analysis of different parts of the fruit-spike}

Bracteoles exhibit epidermal cells with sinuous anticlinal walls, glandular hairs with two secretory cells (Fig. 5) and covering trichomes with deposits of acicular crystals of calcium oxalate (Fig. 6). The venation is reticulate (Fig. 7). The calyx is bilabiate: the upper lip is broad, truncate, three-toothed (Fig. 8) while the lower lip is narrow and split up almost to the middle in 2 lanceolate, acuminate lobes. On the inner margins of the lobes there are only unicellular, bent covering trichomes (Fig. 9, 12) while on the surface and on the outer margins there are unicellular and multicellular covering trichomes (Fig. 10). The epidermal cells of the calyx have sinuous walls and diacytic stomata, one of the subsidiary cells being smaller (Fig. 11, 13). On the outer surface of the lower part of the calyx there are numerous glandular hairs with a monocellular stalk and a bicellular head (Fig. 14).
The base of the flower is covered with short, bi-cellular trichomes (Fig. 15). The style is bilobed with elongated, curved lobes (Fig.16). The endothecium of the anther shows characteristic thickenings (Fig.17). The outer epidermis of the petals is papillose, with conical shaped papillae and striated cuticle (Fig. 18) and shows glandular hairs with four secretory cells (Fig. 20). The filament has a short spur near the insertion site of the anther (Fig.19). The middle lobe of the lower lip is fringed and covered with papillae (Fig. 21, 22).

The transverse section of the wetted nutlet pericarp (Fig. 23) shows: epidermal cells containing mucilage, which become elongated when softened in water; a thin innermost cell layer, and a macrosclereid layer with sinuous anticlinal walls. Nutlets preparations show in surface view elongated macrosclereids (Fig. 24, 25), epidermal cells with straight walls (Fig. 26), and oil droplets in the endosperm (Fig. 27).

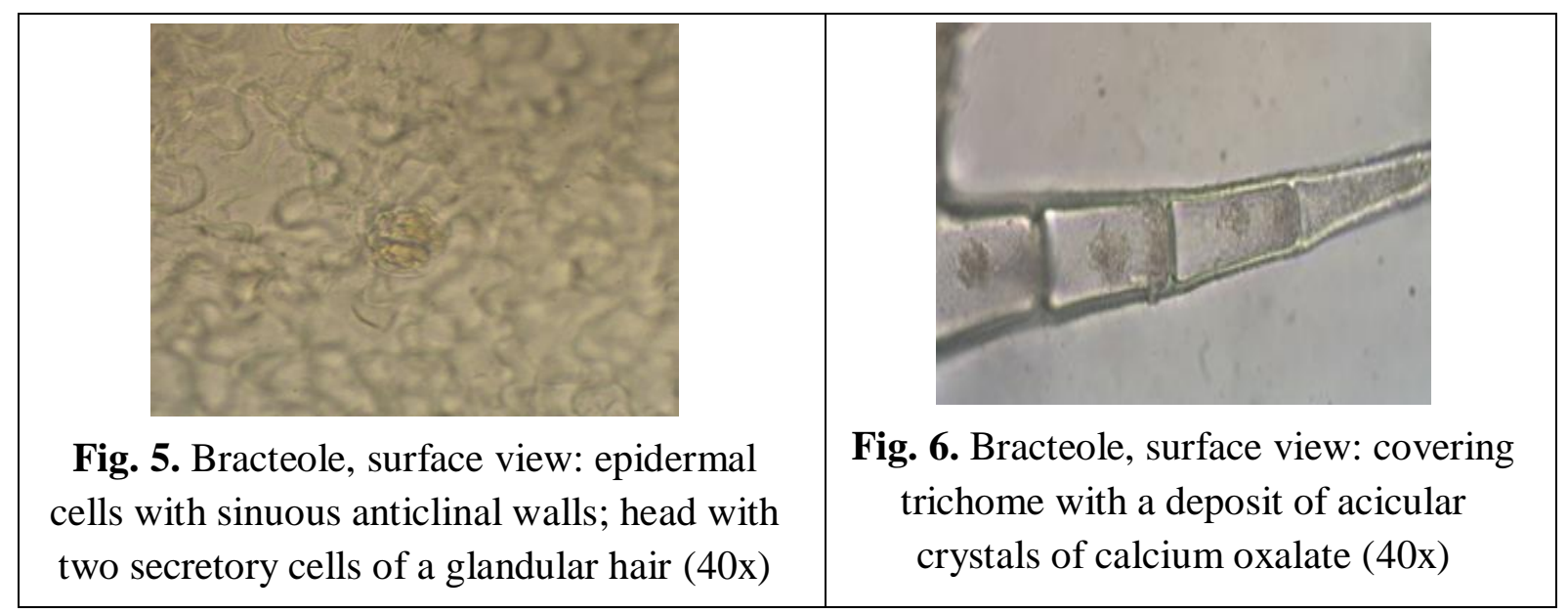




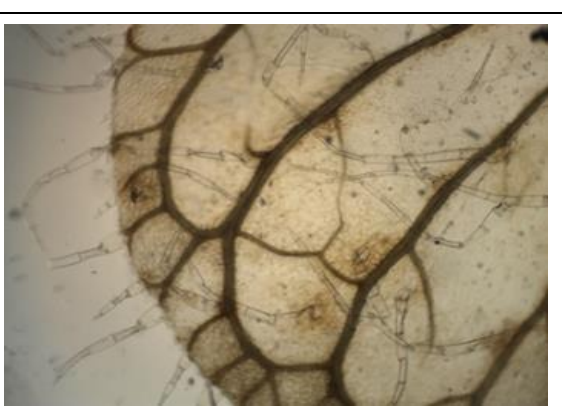

Fig. 7. Bracteole, surface view: reticulate venation, multicellular covering trichomes along the margin and on the surface (40x)

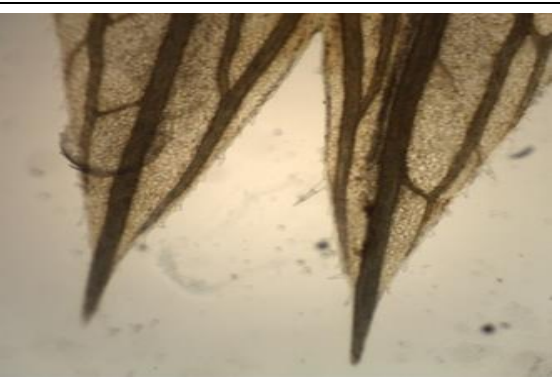

Fig. 9. Calyx, surface view: lower lip with two long acuminated lobes (40x)

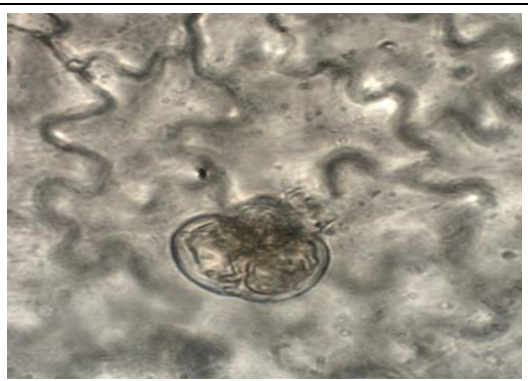

Fig. 11. Calyx, surface view: axially elongated epidermal cells with sinuous anticlinal walls; glandular hair with unicellular stalk and bicellular head (40x)

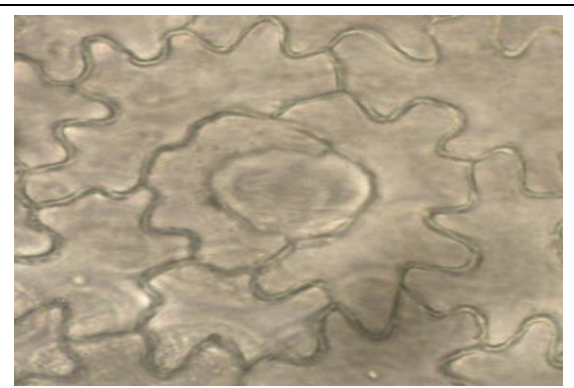

Fig. 13. Calyx, surface view: epidermal cells with sinuous anticlinal walls; diacytic stomata, onsubsidiaryar cell being smaller (40x)

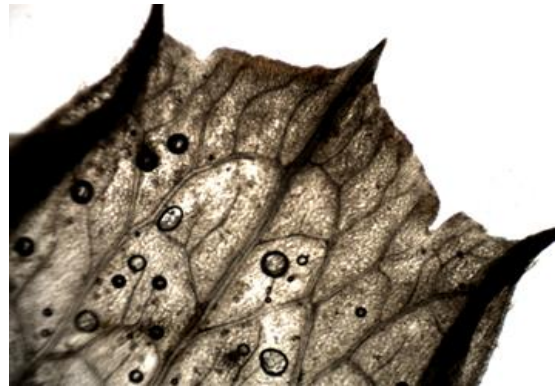

Fig. 8. Calyx, surface view: upper lip, three-toothed (40x)

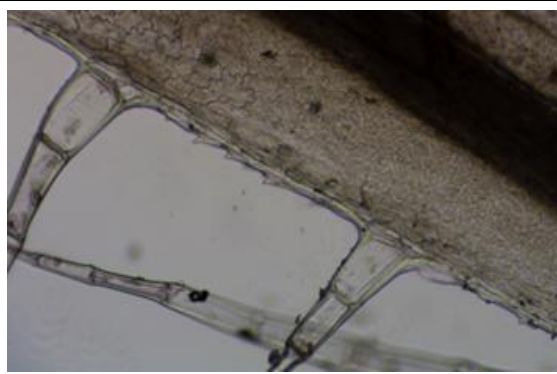

Fig. 10. Calyx, surface view: uni- and multicellular covering trichomes (40x)

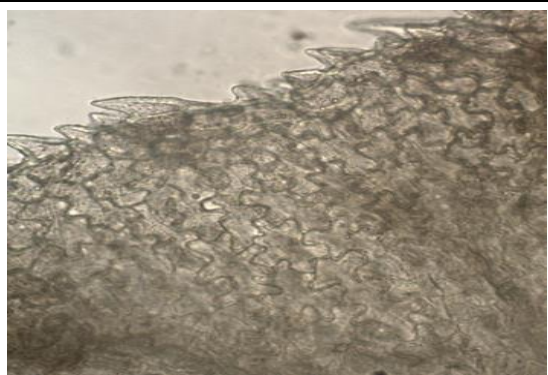

Fig. 12. Calyx, surface view: unicellular, bent covering trichomes along the margin between the lobes (40x)

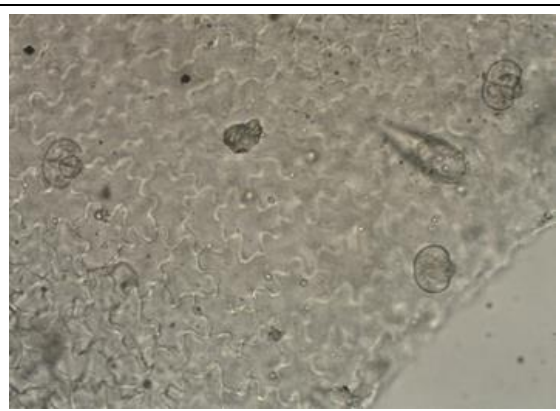

Fig. 14. Calyx, surface view: numerous glandular hairs at the lower region of the calyx (40x) 


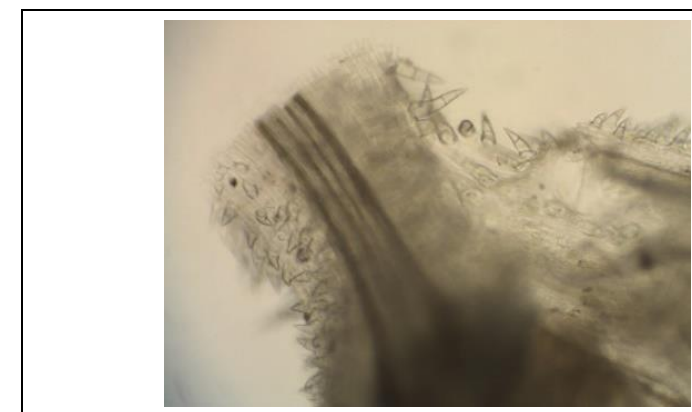

Fig. 15. Flower, surface view: uni- and bicellular trichomes at the base of the petal (40x)

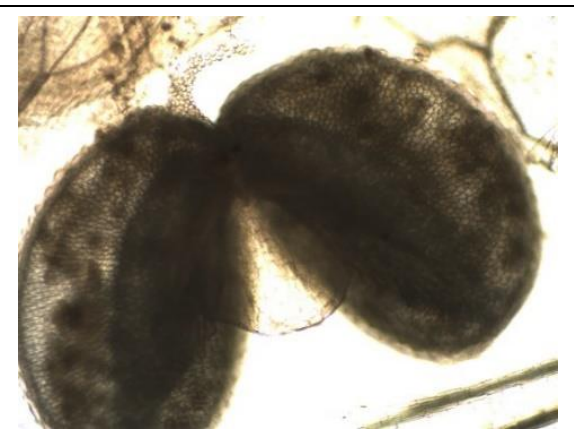

Fig. 17. Flower, surface view: anthers with thickened endothecium (40x)

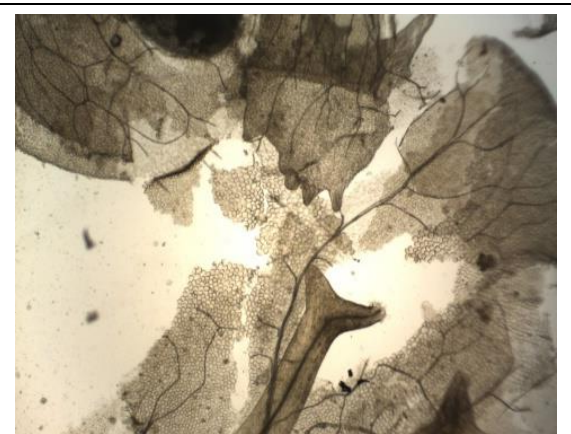

Fig. 19. Flower, surface view: fragments of petals; filament with a spur at the top (40x)

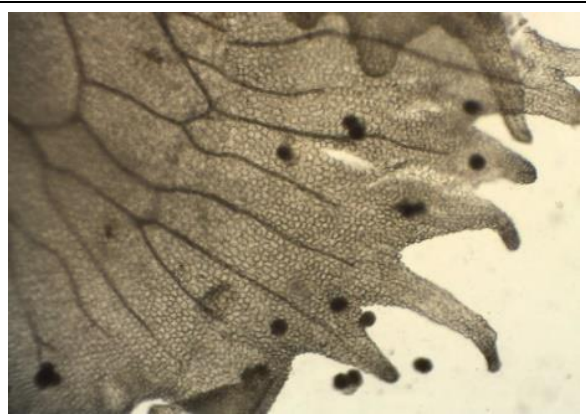

Fig. 21. Flower, surface view: fringed margin of the middle lobe of the lower lip (40x)

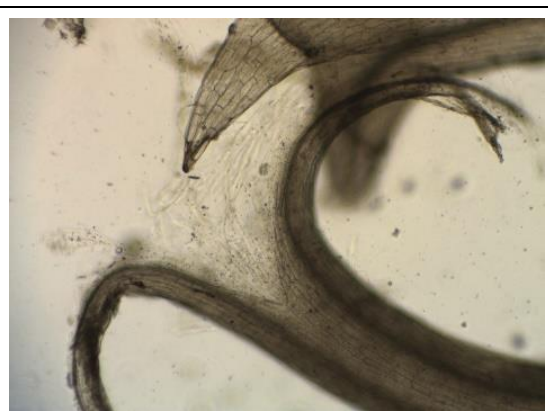

Fig. 16. Flower, surface view: bilobed style (40x)

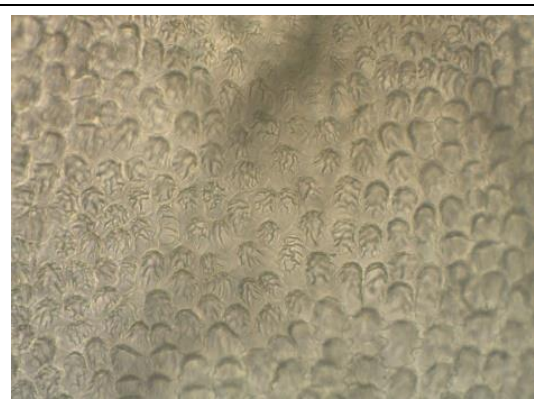

Fig. 18. Flower, surface view: papillose epidermal cells with striated cuticle (40x)

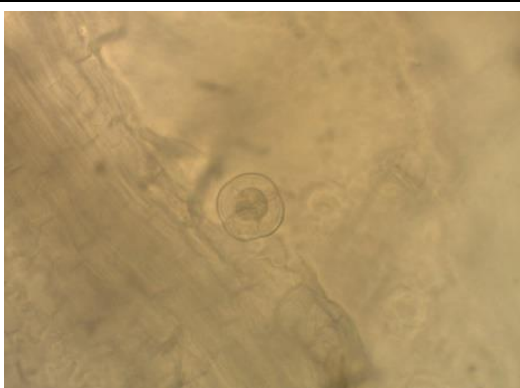

Fig. 20. Flower, surface view: glands with four secretory cells (40x)

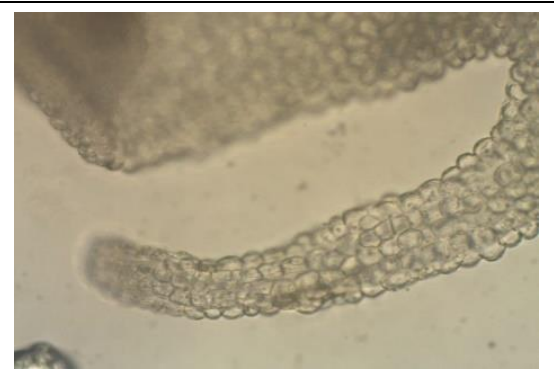

Fig. 22. Flower, surface view: fringe covered with papillae (40x) 


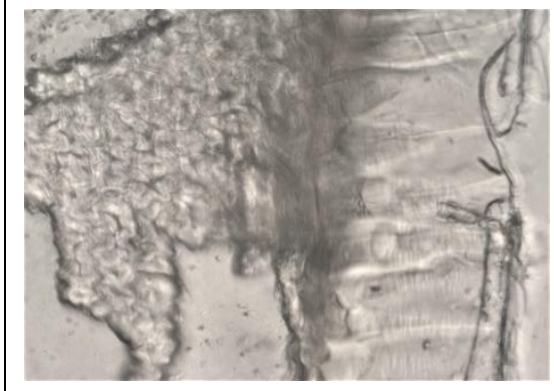

Fig. 23. Nutlet, transverse section: epidermal cells containing mucilage; macrosclereid layer showing sinuous anticlinal walls (10x)

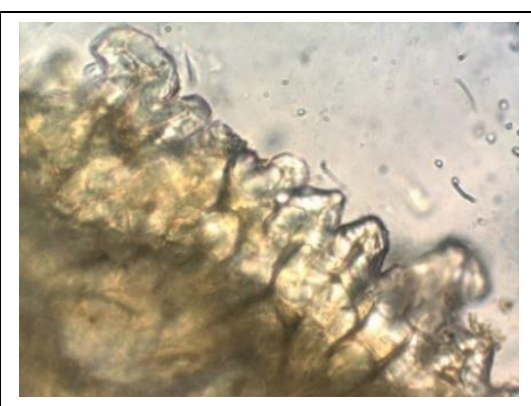

Fig. 24. Nutlet, surface view: elongated macrosclereids (10x)

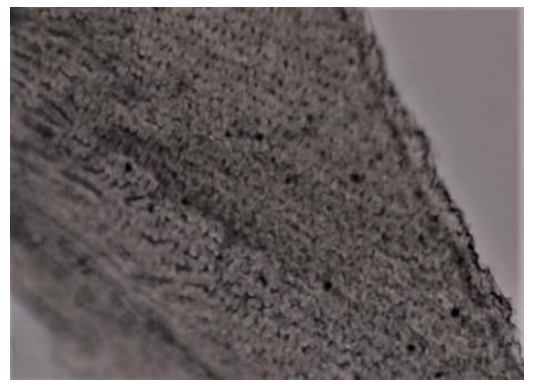

Fig. 25. Nutlet, surface view: macrosclereid layer showing sinuous anticlinal walls (10x)

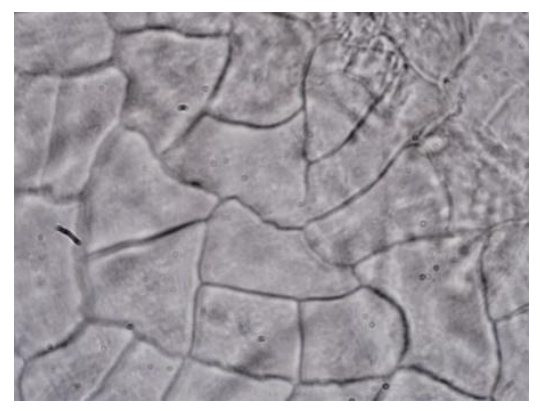

Fig. 26. Nutlet, surface view: epidermal cells with straight walls (10x)

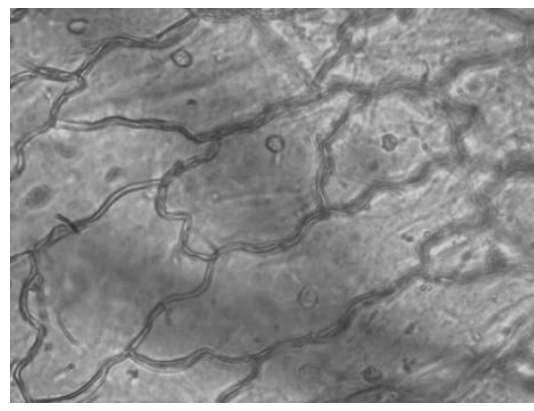

Fig. 27. Nutlet, surface view: endosperm with oil droplets (10x)

(Photos: Alexandra Groșan)

\section{Discussions}

The macroscopic and microscopic analysis of Prunellae spica has highlighted the main characters, which are important to identify this herbal drug and to distinguish it from similar fruit spikes coming from other Lamiaceae species (Moon, 2009).

The analyzed fruit-spike of Prunellae spica (Fig. 1B) has a slightly flattened cylindrical shape, is $1.5-8 \mathrm{~cm}$ long and $0.8-1.5 \mathrm{~cm}$ wide, and has a light brown or reddish-brown color. It consists of 10 or more persistent whorls, each whorl being delimited by two opposite, fanshaped bracteoles, with acuminated tip, with reticulate venation, the outer surface being covered with numerous, conspicuous trichomes. Each bracteole is grown together at the base with three flowers made up of a persistent biconvex calyx, a corolla that usually lacks and four brown nutlets, small and obovate, with a white, sharp protuberance at the hilum. At the fruiting stage, the calyx is closed. The powdered herbal drug is reddishbrown or brown. All these characteristics are in accordance with those acknowledged by European Pharmacopoeia (Eur. Ph. 8.0, 2011).

\section{Conclusions}

The results of our histo-anatomical research confirm the very few and general data from the literature, but also bring new information related to macro- and microscopic characters with practical relevance to botanical identification of the herbal drug Prunellae spica. The nutlets can be easily identified by the Y-shaped mark in the apical region and the three stripes running down to the pyramidal abscission scar near the white hilum. Of the 
microscopic characters, the following should be mentioned: glands with 4 secretory cells on petals; filament with a short conical spur at the top, near the anther; bilobed stigma; glandular hairs with unicellular stalk and bicellular gland on calyx and bracteoles; epidermal cells of calyx and bracteoles with sinuous anticlinal walls and diacytic stomata, one subsidiary cell being smaller.

\section{References}

1. Dınç M, Dogu S (2012) Anatomical and micromorphological studies on Teucrium sect. Isotriodon (Lamiaceae) in Turkey with a taxonomic note. Biologia 67(4):663-672. https://doi.org/10.2478/s11756-012-0049-2.

2. Dinç M, Pinar NM, Dogu S, Yildiriml S (2009) Micromorphological studies of Lallemantia L. (Lamiaceae) species growing in Turkey, Acta Biol Crac Ser Bot 51(1):45-54.

3. Duke J (2001) Prunella vulgaris, Handbook of Edible Weeds. CRC; pp 158

4. Feng ML, Jia LL, Wu YP (2000) Effect of the Alcoholic Extraction of Spica Prunellae on Experimental Diabetic Nephropathy. J Shaanxi Coll Tradit Chin Med 1:7-9.

5. Gu X, Li Y, Mu J, Zhang (2013) Chemical Constituents of Prunella vulgaris, J Environ Sci (China) 25; S1:S161-163. https://doi.org/10.1016/S10010742(14)60648-3

6. Gu XJ, Li YB, Li P, Qian SH, Zhang JF (2007) Triterpenoid Saponins from the Spikes of Prunella vulgaris. Helvet Chim Acta 90: 72-78. https://doi.org/10.1002/hlca.200790023

7. Hodișan I, Pop I (1976) Botanică sistematică, Editura Didactică şi Pedagogică București, pp. 400.

8. Hon-Yeung C, Qing-Feng Z (2008) Enhanced analysis of triterpenes, flavonoids and phenolic compounds in

\section{Conflict of Interest}

The authors declare that the research was conducted in the absence of any commercial or financial relationships that could be construed as a potential conflict of interest.

Prunella Vulgaris L. by capillary zone electrophoresis with the addition of running buffer modifiers. J Chromatogr A 1213(2): 231-238. doi: 10.1016/j.chroma.2008.10.033

9. Huynh HT, Teel RW (1999) Selective Induction of Apoptosis in Human Mammary Cancer Cells (MCF-7) by Pycnogenol. Anticancer Res, 1999; 20: 2417-2420.

10. Hwang YJ, Lee EJ, Kim HR, Hwang KA (2013) In vitro antioxidant and anticancer effects of solvent fractions from Prunella vulgaris var. lilacina. BMC Complement Altern Med 13:310. doi: 10.1186/14726882-13-310

11. Khare CP (2007) Indian Medicinal Plants: An Illustrated Dictionary. Springer; 103.

12. Kozlowska M, Laudy AE, Przbyl J, Ziarno M, Majewska E (2015) Chemical composition and antibacterial activity of some medicinal plants from Lamiaceae family. Acta Pol Pharm 72(4):757-767.

13. Mohsen SM, Ammar AS (2009) Total phenolic contents and antioxidant activity of corn tassel extracts. Food Chem 112(3):595-598. doi:10.1016/j.foodchem.2008.06.014

14. Moon HK, Hong SP, Smets E, Huysmans S (2009) Micromorphology and Character Evolution of Nutlets in Tribe Mentheae 
(Nepetoideae, Lamiaceae). Systematic Botany 34(4):760-776.

https://doi.org/10.1600/0363644097901395 92

15. Psotova J, Kolar M, Sousek J, Švagera Z, Vičar J, Ulrichová J (2003) Biological Activities of Prunella vulgaris Extract. Phytother Res 17:1082-1087. doi:0.1002/ptr.1324

16. Raafat K, Wurglics M, Schubert-Zsilavecz M (2016) Prunella vulgaris L. active components and their hypoglycemic and antinociceptive effects in alloxan-induced diabetic mice. Biomed Pharmacoter 84:1008-1018.

doi: 10.1016/j.biopha.2016.09.095

17. Sârbu I, Ștefan N, Oprea A (2013) Plante Vasculare din România - Determinator ilustrat de teren, Editura Victor B Victor, București 18-22: 650.

18. Tamaș M (1999) Botanică farmaceutică vol III, Ed. Medicală, Cluj; pp. 215.

19. Trochon V, Blot E, Cymbalista F, Engelmann C, Tang RP, Thomaïdis A,
Vasse M, Soria J, Lu H, Soria C (2000) Apigenin Inhibits Endothelial-Cell Proliferation in G2/M Phase Whereas It Stimulates Smooth-Muscle Cells by Inhibiting P21 and P27 Expression, Intern J Cancer 85: 691-696.

20. Wang SJ, Wang XH, Dai YY, Ma MH, Rahman K, Nian H, Zhang H (2019) Prunella vulgaris: A Comprehensive Review of Chemical Constituents, Pharmacological Effects and Clinical Applications. Curr Pharm Des 25(3):356369.

https://doi.org/10.2174/1381612825666190 313121608

21. *** Europea Pharmacopeiaea, 8th edition, 2011, pp. 1219-1220. 